\title{
Positive Parenting or Positive Psychology Parenting? Towards a Conceptual Framework of Positive Psychology Parenting
}

\author{
Theodoros A. Kyriazos, Anastassios Stalikas \\ Department of Psychology, Panteion University, Athens, Greece \\ Email: th.kyria zos@gmail.com
}

How to cite this paper: Kyriazos, T. A., \& Stalikas, A. (2018). Positive Parenting or Positive Psychology Parenting? Towards a Conceptual Framework of Positive Psychology Parenting. Psychology, 9, 1761-1788. https://doi.org/10.4236/psych.2018.97104

Received: June 8, 2018

Accepted: July 10, 2018

Published: July 13, 2018

Copyright (c) 2018 by authors and Scientific Research Publishing Inc. This work is licensed under the Creative Commons Attribution International License (CC BY 4.0).

http://creativecommons.org/licenses/by/4.0/

\section{(c) (i) Open Access}

\begin{abstract}
The purpose of this work is to highlight the distinctiveness of positive psychology parenting from positive discipline and positive parenting. A second purpose is to frame a positive psychology parenting model adopting the principles proposed by Seligman. The parenting research within the positive psychology approach has been rather inactive. This inactivity could possibly be attributed to the parallel use of the term "positive" concurrently by two additional theoretical frameworks apart from positive psychology, i.e. positive discipline and positive parenting. However, in the case of positive discipline and positive parenting, the term "positive" describes a non-punitive, "firm and kind" parenting style. In the case of Positive Psychology, the term positive refers to the broadening and building effect of positive emotions described by Fredrickson. Additionally, the target population of the positive discipline and positive parenting is mainly (but not exclusively) children of special challenges. Finally, their purpose is mainly prevention and treatment. The target population of positive psychology parenting is normally adjusted children and the purpose is well-being and flourishing of the child and family. These three elements-meaning of the term "positive", target population and purposedifferentiate positive discipline and positive parenting from the Positive Psychology parenting model proposed by Seligman. The differences are equivalent to the different approach of "psychology as usual" from positive psychology.
\end{abstract}

\section{Keywords}

Positive Psychology, Positive Psychology Parenting, Authentic Happiness Model, Positive Parenting, Positive Discipline

\section{Introduction}

Every single day, about one million adults become parents for first time (Bornstein 
\& Cheah, 2006). Although most people learn to parent intuitively, with almost no information on child development (Durrant, 2011; Papoušek \& Papoušek, 2002), parenthood has been extensively studied in empirical literature (Bornstein \& Bornstein, 2007), and it is generally accepted that parenting decisively affects child's psychological adjustment (Dwairy \& Dor, 2009; Repetti, Taylor, \& Seeman, 2002; Griffin, Botvin, Scheier, Diaz, \& Miller, 2000; Rasmussen, 2009; Briesmeister \& Schaefer, 2007) and well-being across lifespan (Moore \& Keyes, 2003; Pollard \& Rosenberg, 2003).

The basic concept used is this work which is described next.

A Parent is a significant other with whom a child has a long-term, unique and irreplaceable emotional bond (Rohner, Khaleque, \& Cournoyer, 2012). Within the attachment theory framework parents are attachment figures (Bowlby, 1969).

A family is a system of people in interactivity with a similar proposition (Conoley \& Conoley, 2009; Conoley, Conoley, \& Pontrelli, 2014). In turn, a group of people interacting with a similar proposition is a human open system (von Bertalanffy, 1976). Family systems are based on the General Systems Theory (von Bertalanffy, 1976) suggesting families are better understood when studied holistically taking into account member interactions and environmental influences (Whiteman et al., 2011).

Parenting involves behavior patterns across life-span, among organisms who belong to different generations and they are conspecifics (Lerner, Rothbaum, Boulos, \& Castellino, 2002). More specifically, parenting is considered to be a complex biological and social process (Tobach \& Schneirla, 1968), stretching beyond the provision of food and safety provided by parents to offspring. Consequently, parenting is a lifespan bidirectional process between members of at least two generations, involving other educational, economic, political, and social institutions within a specific cultural context (Ford \& Lerner, 1992; Lerner, Rothbaum, Boulos, \& Castellino, 2002), or in other words a developmental niche (Super \& Harkness, 1986, 1997; Harkness \& Super, 2002). Parenting, parenthood, and child-raising are used interchangeably in this work.

The purpose of the present study is: a) to highlight the differences between positive parenting and positive discipline from Positive Psychology Parenting, and b) to describe a model of Positive Psychology Parenting adopting the parenting principles proposed by Seligman (2002).

\section{Parenting Effectiveness Criteria}

The relationship between parent and child in the light of the systemic view (General Systems Theory, von Bertalanffy, 1976) in developmental psychology (Bronfenbrenner, 1977; Super \& Harkness, 1997; Bornstein, 2002; Lerner, Rothbaum, Boulos, \& Castellino, 2002) is considered to have bidirectionality (Hodapp \& Ly, 2005). Specifically, not only the parental behavior but also the parent-child interaction within the open family-and community-system affect child development (Trommsdorff, 2006). Within this bidirectional framework, 
parental goals and the child temperament were also added (Kuczynski, 2003, cited in Trommsdorff, 2006) as mediating variables in the parent-child relationship quality (Trommsdorff, 2006). Furthermore, the disproportionate effect of parenting quality on children with a "difficult character" as compared to the average child was termed differential susceptibility (Pluess \& Belsky, 2010). In other words, children's development is a compound outcome of the interaction between the characteristics of the children and the ones of the parents or all significant others affecting their socialization (Mussen et al., 1990). The positive psychological adjustment of the child is a measure of parenting effectiveness (Belsky, 2015; Teti \& Candelaria, 2002, cited in Bornstein \& Bornstein, 2007). Parenting effectiveness is described as a set of parental actions that help the child adjust to the environment and successfully utilize opportunities offered (Saegert \& Winkel, 1990, cited in Bradley, 2002). On the other hand, what is considered as a positive parental outcome varies depending on the historical period and the culture (Bradley, 2002). Nevertheless, in the western world, a successfully developed child could generally be described as cooperative, friendly, emotionally stable, reliable, having the potential to be a good, highly educated citizen (Maccoby, 1992). Bradley and Caldwell (1995; Bradley, 2002) proposed a theoretical framework to describe the tasks that parents are required to perform so as to ensure healthy development: 1) sustenance, 2) stimulation, 3) support, 4) structure, and 5) surveillance. The first three tasks are based on what was defined as basic needs in Maslow's Hierarchy of needs (1975; Masters and Masters \& Murphy 1954, as commented by Bradley, 2002) as well as on a similar approach by Ford \& Lerner (1992). The last two functions are complementary to the first three to contingently fit child's needs (Bradley, 2002). Additionally, positive parenting outcomes have been generally related to the following parental practices: basic care, safety, positive emotional support (especially warmth), motivation, consistency and predictability, guidance, and structure (Hurley, Chiodo, Leschied, \& Whitehead, 2003; Rasmussen, 2009).

A plethora of empirical evidence highlights parenting practices that generally boost child's well-being at different developmental phases as follows (summarized by Belsky, 2015). During infancy, sensitive and responsive parenting (parental sensitivity, De Wolff \& van Ijzendoorn, 1997; Goldsmith \& Alansky, 1987) has been reported to build attachment security (De Wolff \& van Ijzendoorn, 1997), child cooperativeness, compliance and moral development (Kochanska et al., 2005). Later, from preschool years to adolescence, authoritative (as opposed to neglectful) parenting (Baumrind, 1967), that is essentially a combination of warmth and firm control with consistent and clear rules, promotes prosocial behaviors, resilience, academic achievement and successful socialization (Ackerman et al., 2004). In adolescence, safeguarding autonomy and individuality contributes to the formulation of psychological and behavioral developmental "outcomes" valued in the western world (Belsky, 2015; Rasmussen, 2009).

Particularly, warm and responsive parenting is associated with cognitive de- 
velopment (Bakeman \& Brown, 1980; Bee et al., 1982; Lyons-Ruth, Connell, Zoll, \& Stahl, 1989), as well as language development (Bee et al., 1982; Clarke-Stewart, 1973), school attainment (Werner \& Smith, 1982), and better psychological adjustment (Maccoby \& Martin, 1983; Pettit \& Bates, 1989). Additionally, warm and affectionate parenting has also been described as sensitive parenting (De Wolff \& van Ijzendoorn, 1997; Goldsmith \& Alansky, 1987) to emphasize the need to convincingly response to the different needs of the child over time (Pickering \& Sanders, 2016). This kind of flexible parenting is linked to the optimal cognitive, behavioral and social outcomes (Belsky et al., 2006; Feldman, 2007, cited in Rilling \& Mascaro, 2016). The gradual shift of parenting ethics to positive facets of child development and well-being is described next.

\section{The Parenting Shift towards Positivity}

All elements of positive physical, social, emotional, and cognitive development of a child are transformable-and presumably, improvable (Bornstein \& Bornstein, 2007; Park \& Peterson, 2006). Nevertheless, rather than focusing on teaching children what is right and wrong, positive parenting focuses on developing children's innate ability to intrinsically tell what is right and what is wrong (Gray, 2007), or to be intrinsically motivated (Bandura, 1997; Ryan \& Deci, 2000; Brown \& Ryan, 2004; Boniwell, 2012). However, there has not been found an agreed definition of positive parenting (Holden, 1985; Patterson, 1992; Pettit et al., 1993), or any method for measuring it (Conger et al., 1993; Patterson, 1992; Pettit et al., 1993) as noted by Russell and Russell (1996).

Specifically, positive parenting, including warmth, affection, monitoring, positive engagement (Caspi et al., 2004; Smith, Landry, \& Swank, 2000), and involvement was reported to be a protective factor against poor developmental outcomes (Bishop \& Rothbaum, 1992; Feldman, Rosenthal, Mont-Reynaud, Leung, \& Lau, 1991; Gardner, 1987, 1992; Holden, 1983, 1985; Pettit \& Bates, 1989; Pettit, Bates, \& Dodge, 1993, as quoted by Russell \& Russell, 1996). Drawing on the work of Adler (1958) and Dreikurs and Soltz (1964), numerous conceptual frameworks were proposed for child-raising, carrying the adjective "positive". This parenting ethics shift towards positivity was followed by the United Nations Children's Rights Declaration (UNF, 2006).

The most influencing theoretical frameworks include the following: a) Positive Discipline (Nelsen, 1979, 2006; Durrant, 2011); b) Positive parenting (Sanders, 2003); c) The Positive Psychology Movement (Seligman \& Csikszentmihalyi, 2000); d) Positive Psychology Parenting (Seligman, 2002).

Positive Discipline Overview. Positive Discipline (Nelsen, 1979, 2006; Durrant, 2011) is a parental and classroom management method that excludes physical punishment and uses positive reinforcement and other techniques that encourage positive behaviors discouraging negative ones. As Adler proposed, Positive discipline is based on a "kind and firm" (or democratic) approach to teaching and parenting (Adler, 1958; Dreikurs \& Soltz, 1964; Nelsen, 1979, 2006). Unlike behaviorism, it encourages internal locus of control (Nelsen, Lott, \& Glenn, 
2000). Positive discipline, as framed by Nelsen, elaborates the work of Baumrind (1967) on parenting styles. It emphasizes on long-term benefits of the "kind and firm" parenting style in contrast to styles with only short-term effectiveness-if any-including controlling, permissive and neglectful parenting styles (Lott \& Nelsen, 2000). The kind and firm discipline style has also been proposed as a classroom management method (Nelsen, Lott, \& Glenn, 2000). A different model of positive discipline equates discipline to teaching a set of principles with the purpose of learning children how to succeed and acquire knowledge, by eliminating all violent parent-child interactions (Durrant, 2011). Positive discipline excludes violence and it is solution-oriented (Durrant, 2011). In this case, the target population is children with "particular challenges that are not typical for their age" (Durrant, 2011). The term "positive" by this approach describes a non-authoritarian control practice (Nelsen, 1979, 2006) or the avoidance of parent violence (Durrant, 2011) to correct an unwanted child behavior.

Positive Parenting Overview. In a similar vein, Positive Parenting, generally implemented by the Triple-P Positive Parenting program (Sanders, 1999, 2008), while centered around positive discipline, it extends positive practices beyond parental control to include every aspect of parental behavior, as well as satisfaction from the parental role and realistic expectations for the child. The emphasis of this positive parenting model-like Durrant's (2011) approach-is put on stopping child maltreatment and abuse, enhancing at the same time parental warmth and satisfaction from a parent-child relationship (Sanders, 2012). The Triple P-Positive Parenting Program adopts a public health framework focusing on warm, consistent parenting and contingent discipline in a low-conflict family setting (Pickering \& Sanders, 2016). Triple P, adopting the principle of proportionate universalism targets to both early intervention and prevention. The program covers all developmental stages from infancy to adolescence and the interventions can vary from narrow for at-risk children/parents to broad for largescale interventions (Pickering \& Sanders, 2016).

Generally, parenting programs are oriented towards prevention and treatment of social, emotional and behavioral problems including children with developmental disabilities (Tellegen \& Sanders, 2014; Whittingham, Sanders, McKinlay, \& Boyd, 2014), feeding problems (Adamson, Morawska, \& Sanders, 2013), anxiety disorders (Rapee, Kennedy, Ingram, Edwards, \& Sweeney, 2010), recurrent pain syndromes (Sanders, Cleghorn, Shepherd, \& Patrick, 1996), or childhood obesity (West, Sanders, Cleghorn, \& Davies, 2010) as reported by Pickering and Sanders (2005).

On the other hand, parenting programs are limited to few recommendations due to "inconclusive results" probably attributed to developmental differences, in an attempt to include all possible families (Durlak, 2003, cited in Weissberg, Kumpfer, \& Seligman, 2003), i.e. the public health approach (Pickering \& Sanders, 2005; Sanders, 2008).

The Positive Psychology Movement Overview. Although Positive Psychol- 
ogy is not exclusively oriented to parenting, it brought about a change in the outlook of "psychology as usual" (i.e. classic psychology, Seligman \& Pawelski, 2003; Hefferon \& Boniwell, 2011; Seligman, Railton, Baumeister, \& Sripada, 2016) that can also affect parenting practices (Seligman, 2002).

It has been twenty years since Martin Seligman, as the new APA president addressed to the 107th Annual Convention of the American Psychological Association in Boston, on August 21, 1999 (Linley et al., 2009), announcing the Positive Psychology movement, an umbrella term for the empirical study of "what makes life worth living" (Peterson, 2013; Seligman, 2011). Thus, the purpose of Positive Psychology has been to study all factors contributing to human flourishing on both a personal and a community level (Gable \& Haidt, 2005; Linley \& Joseph, 2015).

In fact, Martin Seligman used his 2000 term presidency of the American Psychological Association (Seligman \& Csikszentmihalyi, 2000) to communicate the disproportionate focus of "psychology as usual" on pathology (Wood \& Johnson, 2016; Schueller \& Parks, 2014) and to propose a new orientation to human functioning, based on solid, empirical evidence (Seligman, 2011). Seligman diverted this, now bourgeoning discipline, to the study of well-being (Ryff \& Keyes, 1995; Keyes, 2002; Vittersø et al., 2010), happiness (Diener, 2000), flourishing (Seligman, 2011; Diener et al., 2009, 2010), and the life well-lived (cited in Burns, 2010). During these early stages, there was a need for positive psychology to highlight the inferential error of equating well-being to the absence of mental illness (Seligman, 2002, 2006; Fredrickson, 2013a). To this end, the Jahoda (1958) model of mental health/illness was used. This is a continuum with mental illness on one end rated at -8 and mental health on the opposite end rated at +8 . Zero indicates the absence of mental illness (Seaton, 2009). According to (Seligman, 1998; Seligman \& Csikszentmihalyi, 2000) "psychology as usual" mostly focused on helping individuals move from -5 to -2 while positive psychology focuses on helping individuals move from +2 to as high as possible (Hefferon \& Boniwell, 2012), seeking well-being.

Well-being is defined as the positive evaluation of life by the individual (Seligman, 2002; Diener \& Seligman, 2004). Ryan and Deci (2001) relate well-being to optimal experience (like flow; Csikszentmihalyi, 1975/2000) and generally to optimal psychological functioning (Keyes, 2002; Huppert \& So, 2013; Kahneman, Diener, \& Schwarz, 1999). Only when basic needs are satisfied well-being can be achieved (Maslow, 1968, 1975; Boniwell, 2012). The World Health Organization also defined health in relation to well-being as follows: "a state of complete physical, mental and social well-being and not merely the absence of disease or infirmity" (WHO, 1978).

In a similar vein, flourishing is a mental health state that has psychological vigor originating from feeling well and doing well on a personal and community level, free from psychopathology and mental distress (Fredrickson \& Losada, 2005; Seligman, 2011). Of course, mental problems cannot be eliminated, nevertheless, they loom larger by the exclusive focus of psychology on the human 
weaknesses (Snyder et al., 2002). Crucially, the purpose of positive psychology is not to advise people to be happy or optimistic but to provide solid evidence of the positive impact of well-being on human functioning (Seligman, 2007, 2011).

Thus, positive psychology is the study of positive emotions (as defined within the Broaden and Build framework; Fredrickson, 1998, 2001) and character strengths (Snyder \& Lopez, 2007). According to Seligman (2002) Positive Psychology has three pillars: the study of positive emotions is the first through the framework of Broaden and Build theory (Fredrickson, 1998, 2001), the study of character strengths and virtues (Seligman \& Peterson, 2004; Park, 2009) is the second and the study of positive institutions comes third (Seligman, 2002). Strong families are considered to be an institution nurturing positive emotions and character strengths through parenthood. Thus, strong flourishing families are the setting of parenting with the principles of positive psychology (Seligman, 2002).

Positive Psychology Parenting Overview. In "Authentic Happiness" (2002), shortly after the launch of the Positive Psychology movement, Seligman described Positive Psychology parenting. Positive Psychology parenting is based on the fundamental principles of Positive Psychology, i.e. positive emotions and character strengths and values (Seligman, 2002).

The purpose of Positive Psychology parenting (Seligman, 2002) is to provide positive emotions and also to find and elaborate child's character strengths, thus to promote well-being. In the long, the goal of Positive Psychology parenting is to help the child structure his life (i.e. education, career, hobbies) around his most frequently used character strengths. During this process, the whole family's well-being and signature strengths are also enhanced. These two elements, positive emotions and character strengths are the backbone of both Positive Psychology and Positive Psychology parenting (Seligman, 2002).

Crucially, unlike positive discipline, Triple-P positive parenting and other similar approaches, the target group of positive psychology parenting is normally adjusted children (Seligman, 2002), in agreement with positive psychology. Note also that in this context, the adjective positive denotes positive emotions within the Broaden and Build theoretical framework (Fredrickson, 2001) and not non-punitive parenting practices.

To put it in a nutshell, children's well-being has been conceptualized to be merely the absence of psychological maladjustment, or/and the presence of positive outcomes regarding academic, interpersonal, athletic, and artistic success (Scales, Benson, Leffert, \& Blyth, 2000). The primary focus of academic work has been on the cure of psychological maladjustment, especially childhood disorders, deficits and disabilities or the development of prevention-oriented interventions (Bornstein \& Bornstein, 2007). Actually, the focus on these behaviors have stimulated the formulation of numerous programs, even public health policies to prevent child maladjustment (Catalano, Berglund, Ryan, Lonczak, \& Hawkins, 1999).

When Seligman founded Positive Psychology (Seligman \& Csikszentmihalyi, 
2000), he laid the foundations of child-raising within the Positive Psychology perspective. Until then, parenting was commented by the founder of Positive Psychology (2002) as follows: There is a need for a better psychology for all normally adjusted children that equally studies positive emotions as distressing ones, at work, marriage, and parenting and will help children use their strengths every day in all life domains (Seligman, 2002: p. 11).

In the positive psychology parenting model proposed here three essential differentiations pinpoint the dissimilar approach of positive psychology parenting from the positive discipline and the positive parenting as follows: a) the target group; b) the general orientation, and finally c) the content that the adjective "positive" receives. The dissimilarities can be attributed to the different orientation of positive psychology in comparison to "psychology as usual" (Boniwell, 2012; Hefferon \& Boniwell, 2011; Seligman, 2002; Seligman \& Pawelski, 2003). Of course this is not to say that other parenting models are less positive, or even less effective, but to highlight they are orientated primarily in prevention and treatment in line with the purpose of "psychology as usual", while the proposed positive psychology parenting model is orientated to the flourishing of all normally adjusted children through broadening and building positive emotions and cultivating character strengths in line with the purpose of positive psychology (see Table 1 for an outline).

Next, the construct of positive psychology parenting is described in more detail.

\section{The Principles of Positive Psychology Parenting}

According to Seligman (2002), two core elements that enable children to flourish are 1) positive emotions as defined by Broaden and Build Theory (Fredrickson, 2001), and 2) the character strengths (Seligman \& Csikszentmihalyi, 2000). Character strengths are a sub-category of personality attributes having a moral value, e.g. politeness as opposed to introversion which has no moral dimension (Peterson \& Park, 2009). Fredrickson defines character strengths as habits (Fredrickson, 2009).

Regarding positive emotions, Seligman (2002) lists as important the emotions of joy, hope, interest, curiosity, and several others. Moreover, after two decades of extensive research the top-ten of positive feelings are (in order of importance): joy, gratitude, serenity, interest, hope, pride, fun, inspiration, awe and love (Fredrickson, 2009; Hefferon \& Boniwell, 2012).

Concerning character strengths, their importance is evidenced by the expectation of parents from their children. Most of them wish their offspring to have a character strength such as kindness, politeness, etc. (Seligman, 2002; Seligman, Park, \& Peterson, 2006). Generally, research into parents-to-be suggests their expectations from their children are definitely in the Positive Psychology research scope: health and happiness, job satisfaction, character strengths and values, contribution to the common good (Cameron, Dutton, Quinn, \& Wrzesniewski, 2003) and generally concern all life domains (Moore \& Lippman, 2005). 
Table 1. Orientation comparison of positive discipline, positive parenting and positive psychology parenting.

\begin{tabular}{|c|c|c|c|}
\hline & Positive Discipline & Positive Parenting & Positive Psychology Parenting \\
\hline Goal & Prevention \& Treatment & Prevention \& Treatment & Flourishing \\
\hline Jahoda (1958) model goal & $\begin{array}{l}\text { Move from }-2 \text { to zero } \\
\text { (no mental disease) }\end{array}$ & $\begin{array}{l}\text { Move from }-2 \text { to zero } \\
\text { (no mental disease) }\end{array}$ & Move from 0 to as high as possible \\
\hline Target Group & Cases with special challenges & Special \& General population & General population \\
\hline Family level impact & $\begin{array}{l}\text { No unpleasant parent-child } \\
\text { interactions }\end{array}$ & Low-conflict family environment & $\begin{array}{l}\text { Good/meaningful life for the whole } \\
\text { family }\end{array}$ \\
\hline "Positive" means & $\begin{array}{l}\text { Non-violent, non-punitive parenting } \\
\text { or Kind \& Firm parenting }\end{array}$ & $\begin{array}{l}\text { Non-violent, non-maltreating } \\
\text { parenting }\end{array}$ & $\begin{array}{l}\text { Positive emotions and their } \\
\text { Broadening and building effect } \\
\text { proposed by Fredrickson (2001) }\end{array}$ \\
\hline & (Durrant, 2011; Nelsen, 2006) & (Sanders, 2012) & (Seligman, 2002) \\
\hline
\end{tabular}

Positive Psychology seeks to answer the following questions as far as parenting is concerned according to Seligman's (2002) own words:

"Can there be a psychological science that is about the best things in life? Can there be a classification of the strengths and virtues that make life worth living? Can parents and teachers use this science to raise strong, resilient children ready to take their place in a world in which more opportunities for fulfillment are available?" (Seligman, 2002: p. 11).

Regarding the target group of Positive Psychology Parenting, the disease/health model (Jahoda, 1958) was used to establish the target group, and the purpose of Positive Psychology parenting. Seligman describes it as follows:

"Raising children, I knew now, was far more than just fixing what was wrong with them. It was about identifying and amplifying their strengths and virtues and helping them find the niche where they can live these positive traits to the fullest"(Seligman, 2002: p. 11).

Seligman (2002) put parenting in the realm of the good life, defining it as follows. Child raising is an opportunity to: a) Apply the principles of Positive Psychology to increase well-being and flourishing of the parent and the child alike; b) Increase the level of positive emotions to the child; c) Discover strengths and signature strengths and then nurture these signature strengths; d) Forge child's life around his/her signature strengths as a means of balancing his/her weaknesses and as a source of well-being.

The parenthood Seligman (2002) proposed is based on the pillars of Positive Psychology as presented in Table 2.

\section{Positive Emotions: The $1^{\text {st }}$ Pillar of Positive Psychology Parenting}

In line with the Broaden and Build Theory of Positive Emotions (Fredrickson, 1998, 2001), Seligman (2002) vividly describes that evolution has favored both types of emotions, positive and negative. Negatives serve as a survival advantage by narrowing awareness, to permit to the threatened individual to focus on survival (Fredrickson, 2003). Negative emotions such as fear, disgust, and anger are a defense against external dangers, essentially a win-lose situation, where the net result is zero (zero-sum games; Seligman, 2002). On the other hand, positive emotions broaden our awareness (Fredrickson \& Branigan, 2005; 
Table 2. The pillars of positive psychology parenting as defined by Seligman (2002).

$\begin{array}{ll}\text { Pillar } 1 & \begin{array}{l}\text { Positive Emotions. Positive emotions of the child are considered to be of key impor- } \\ \text { tance. }\end{array} \\ \text { Pillar } 2 & \begin{array}{l}\text { Character Strengths. Knowing and using character strengths and values in all realms of } \\ \text { life (play, education, activities) }\end{array}\end{array}$

Rowe, Hirsh, \& Anderson, 2007; Wadlinger \& Isaacowitz, 2006), can undo negative emotions (Fredrickson \& Levenson, 1998; Fredrickson et al., 2000), buffer against adversity (Fredrickson, Cohn, Coffey, Pek, \& Finkel, 2008), and finally fuel more positive emotions (upward spiral; Fredrickson, 2003; Garland, Fredrickson, Kring, Johnson, Meyer, \& Penn, 2010). Natural selection (Darwin, 1871) has favored negative emotions because they offered our ancestors better chances of survival, Seligman (2002) comments.

Thus, Broaden-and-Build theory of positive emotions describes why we inherited both positive and negative emotions (Fredrickson, 1998, 2001, 2013), balancing the importance of positive emotions to the negative ones (Seligman, 2002). For Seligman (2002), this directly opposes to the psychoanalytic theory (Freud, 1962; see also Mussen, Rutherford, Harris, \& Keasey, 1970), the prevailing theory in psychology literature at that time, postulating that negative emotions are the foundations of negative motivation and that positive motivation is simply fueled by the negative one. Besides, he concludes that this "rotten-to-thecore" dogma is empirically unfounded (Seligman, 2002). Moreover, this dual view of emotions, which gives both negative and positive emotions the same evolutionary value, is also the basic assumption for human motives from the perspective of positive psychology (Seligman, 2002).

After two decades of research, empirical evidence (as reviewed by Fredrickson, Cohn, Coffey, Pek, \& Finkel, 2008) suggests that positive emotions are related to many positive outcomes like better socialization and social support (Waugh \& Fredrickson, 2006), openness to new acquaintances (Dunn \& Schweitzer, 2005), constructive feedback (Raghunathan \& Trope, 2002), marital satisfaction and happy marriage (Harker \& Keltner, 2001), higher income (Diener, Nickerson, Lucus, \& Sandvik, 2002), better health (Doyle, Gentile, \& Cohen, 2006), and even longevity (Danner, Snowdon, \& Friesen, 2001; Ostir, Markides, Black, \& Goodwin, 2000).

Fredrickson's (2001) Broaden and Build theory has consequences for a child that are "broadening, building, and abiding" as Seligman (2002) describes. Positive emotions for Seligman (2002) promote growth and pinpoint a win-win situation for the child and the parents. This may be because in general they nurture trust in personal relations (Hejmadi, Waugh, Otake, \& Fredrickson, 2008) and openness to new experiences (Dunn \& Schweitzer, 2005), and they undo negative emotions (Fredrickson, 2003; Fredrickson \& Levenson, 1998; Fredrickson et al., 2000). They also add positive resources that in times of hardship can act as a buffer, or a protective mechanism of resilience (Fredrickson, 2013b).

Moreover, when children have a positive emotion, they think more creatively 
and resourcefully, and they are more willing to start exploring their environment (Seligman, 2002). Exploration builds knowledge and mastery and through this process of skill acquisition, the strengths of character gradually emerge. For this reason, positive emotions are plentiful to small children, Seligman (2002) explains. Seligman also comments that positive emotions fuel creativity and help in building skills and mastery. Those, in turn, generate more positive emotions and more creativity and mastery (Seligman, 2002). This ongoing cycle of positivity (upward spiral; Fredrickson, 1998, 2001) is quite important for the secure attachment of the child (Seligman, 2002).

Crucially, up-to-date empirical evidence suggests that positive emotions' effects have an Inverted-U curve. This means that the more positive emotions, the better for the individual but only up to a point (Diener, Colvin, Pavot, \& Allman, 1991). Similar findings, Fredrickson (2013b) explains, were also reported for creativity (George \& Zhou, 2007), income and political participation (Oishi, Diener, \& Lucas, 2007). This nonlinearity is directly differentiated from the linear models of psychological phenomena (Frederickson \& Losada, 2005; Fredrickson, 2013b). Nevertheless, this may not necessarily be true for parenthood, because Seligman (2002) notes that positive emotions can be abundant to children and are offered unconditionally. More specifically, Seligman (2002) postulates the three fundamental principles of Positive Psychology Parenting (see Table 3).

According to the first principle of positive psychology parenting, positive emotions help children to build resources at an emotional, cognitive, social and even physical level (Seligman, 2002), and at the same time to gather positive resources to draw from when facing adversity (Seligman, 2002; Fredrickson, 1998, 2001, 2009, 2013b). On the contrary, every time children experience negative emotions, they have the innate tendency to protect themselves, thus they search for a familiar, safe place, and when unavailable they freeze in their place (Seligman, 2002), i.e. reacting impulsively.

Then, Seligman (2002) adds, when they will feel safe again they will leave their sanctuary, starting to explore again the world by playing. Exploration causes even more positive emotions, or in other words an upward spiral of positive emotions (Fredrickson, 1998, 2001, 2003), as stated in the second principle of positive psychology parenting, in the child (Seligman, 2002) as well as in the adult (Fredrickson, 1998, 2001, 2009, 2013b). This process could be comparable to circular causality (von Bertalanffy, 1976), described by the systemic view of

Table 3. The three core principles of Positive Psychology Parenting as described by Seligman (2002).

Positive emotions broaden and build (Fredrickson, 1998, 2001) cognitive, social,

Principle 1 emotional and physical resources and capitalize them for children to rely on them later in life.

Increasing positive emotions in children can initiate an upward spiral of positive

Principle 2 emotions according to the Broaden and Build theory of Positive Emotions (Fredrickson, 1998, 2001).

Principle 3

The positive traits children show are equally important to the negative ones (Seligman, 2002). 
child development (Bronfenbrenner, 1977; Super \& Harkness, 1997; Bornstein, 2002; Lerner, Rothbaum, Boulos, \& Castellino, 2002).

Furthermore, positive emotions are directly related to secure attachment (Bowlby, 1969; Ainsworth et al., 1978). Positive emotions expressed by mothers to children facilitate secure attachment especially during infancy or later (Juffer, Bakermans-Kranenburg \& van Ijzendoorn, 2008). It is empirically supported that the surely attached children perform better than non-securely attached children in problem-solving, creativity and exploration, independence, enthusiasm, and resilience (van Ijzendoorn, Bakermans-Kranenburg, \& Sagi-Schwartz, 2006; Juffer, Bakermans-Kranenburg \& van Ijzendoorn, 2008). The second pillar of positive psychology parenting (Seligman, 2002) is the character strengths of children and the whole family in general, with the purpose to build a niche (Super \& Harkness, 1997, 1986) where any family member can flourish (Seligman, 2011) pursuing the good life (Seligman, 2002).

A parenting style expressing positive emotions like warmth, involvement, and affection is the authoritative parenting style (Baumrind, 1967, 1971). This has been essentially reported to have positive parenting outcomes with regard to children's psychological adjustment and perceived well-being (Rasmussen, 2009). Besides, a warmer parent-child relationship can reinforce secure attachment (c.f. Seligman, 2002), positive intellectual, social and emotional development, higher school performance and academic perspective, and better socialization. Finally, according to the same source (Rasmussen, 2009), the children of warm and expressive parents have a higher self-esteem as well as greater optimism, and higher subjective well-being (see Diener, 1984), a finding reported especially among adolescent samples (Baumrind, 1991; Milevsky et al., 2007; Jach et al., 2018; Schwartz et al., 2012).

\section{Character Strengths Are the $2^{\text {nd }}$ Pillar of Positive Psychology Parenting}

The empirical literature has been a central focus of Positive psychology and has been really rich (Seligman, 2009). Positive characteristics have been reported to predict well-being (Park, Peterson, \& Seligman, 2004) as well as performance (Park \& Peterson, 2006). Furthermore, positive traits are changeable (Seligman, Steen, Park, \& Peterson, 2005) and teachable (Shoshani \& Slone; 2013; Proctor et al., 2010; Eades, 2008; Park \& Peterson, 2009; McGovern \& Miller, 2008), as commented in Ng, Cao, Marsh, Tay and Seligman (2017).

Thus, a classification model of positive psychological traits, or to put it differently, character strengths, can diagnose and enhance flourishing (Peterson, 2006). Seligman (2002) recommends VIA Classification version for children (VIA, Mayerson Foundation, 2000; VIA-Youth Classification, (Seligman \& Peterson, 2004) to identify their signature strengths (Peterson \& Seligman, 2004). The instrument consists of six categories of 24 pan-cultural character strengths and values (Peterson \& Seligman, 2004). According to VIA Classification of Character Strengths and Values (Peterson \& Seligman, 2004), the most frequently displayed character strengths are the signature strengths of the child (Peterson \& Seligman, 2004; Seligman, Steen, Park \& Peterson, 2006; Peterson \& 
Park, 2009). Generally, parents have a major influence on the character of their offspring (Gardner et al., 2001, 1988, cited in Park, 2004).

In the light of the above findings, a new research field was developed, studying the use of character strengths in relation to many well-being variables in adults (Seligman et al., 2005), students (Allan \& Duffy, 2014), and children in relation to reprieved life satisfaction (Proctor et al., 2010; Suldo et al., 2014; Waters, 2015), school adaptability (Shoshani \& Slone, 2013), and finally hope and resilience (Waters, 2015).

Indeed, character strengths and values are the links between Positive Institutions (in this case parenthood and family) and positive emotions (Park \& Peterson, 2009). Nevertheless, positive psychology only recently began to study parenthood in relation to the child's strengths and values as part of the parenting process (Rasmussen, 2009; Huta, 2012; Waters, 2015; Jach et al., 2018), despite its interest in positive education (Fox \& Fades, 2008), and positive youth development (Larson, 2000). Furthermore, developmental psychology was equally unmotivated both for studying positive youth development (Larson, 2000) and character strengths' development (Park, 2004).

Seligman (2002) comments that discovering and building character strengths and values is like the acquisition of the language (Seligman, 2002). During this process, Seligman (2002) stresses that on the appearance of character strengths or values, parents must identify, name and praise it, to motivate the child to repeat, acquire and eventually enhance it. Empirical research has subsequently confirmed Seligman's premise, since the well-being of children and youngsters was greater when their parents identified and encouraged their character strengths (Waters, 2015).

The increase of positive emotions in children by their parents promotes secure attachment and enhances playfulness, creativity, resourcefulness, and exploration as Fredrickson $(1998,2001,2013 b)$ initially proposed, and as Seligman further elaborated about children (Seligman, 2002; see also Figure 1). This creative state boosts experimentation, therefore, children can develop many different skills (Seligman, 2002). In turn, increasing skills causes even more positive emotions (an upward spiral of positive emotions, Fredrickson, 1998, 2001, 2013b). Crucially, throughout this explorative and creative phase, character strengths and values are being discovered and built (Seligman, 2002). Seligman (2002) further notes that some character strengths will appear and then disappear while others will recurrently keep reappearing again and again.

Furthermore, Seligman (2002) suggested to adapt the child's education to his/her character strengths and values. In line with this idea, subsequently, a rich empirical research followed focusing on the enactment of character strengths and values in parenting. Besides, character strengths have been successfully integrated within some educational curricula (Eades, 2008; Park \& Peterson, 2009) or educational institutes (Geelong Grammer School in Australia) and also in an academic learning environment (McGovern \& Miller, 2008). 


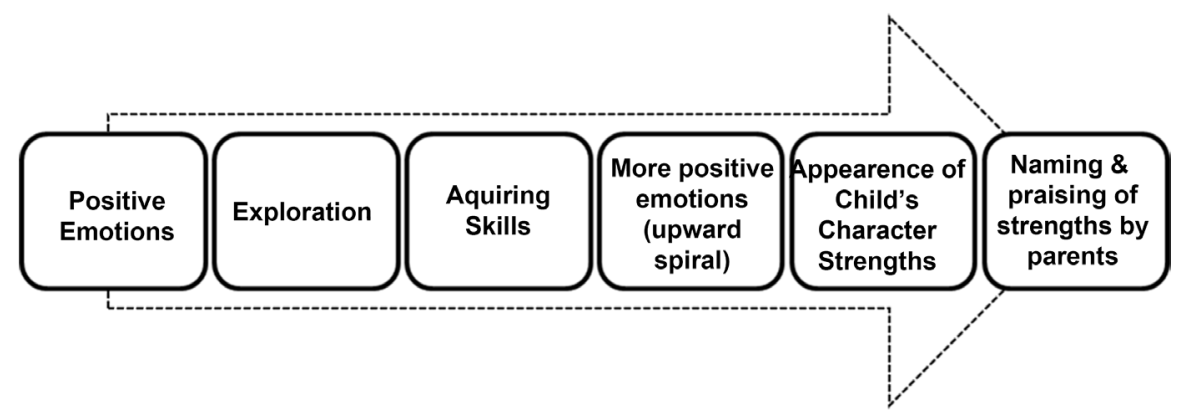

Figure 1. How positive emotions are related to Character Strengths (Seligman, 2002).

A large part of the empirical research on character strengths was focused on elaborating their impact on the well-being of children and adolescents, under different conditions: being aware of their character strengths and using them, and not being aware of them and not using them or being aware of them and not using them (Govindji \& Linley, 2007; Proctor et al., 2010; Seligman et al., 2005). The knowledge and use of character strengths contribute more to well-being and life satisfaction (Waters, 2015; Govindji \& Linley, 2007). Interventions in pupils showed similar results (Quinlan et al., 2012). Additionally, positive role modeling (Bandura, 1997; Huta, 2012) is also considered to be of great importance for the development of character strengths (Park \& Peterson, 2009; Waters, 2015; Huta, 2012) and for agency and pathways mindset (Snyder, 2000). Note that parents can also integrate their own character strengths in their parenting role to improve parenting practices (Rasmussen, 2009).

Generally, character strengths have been reported to correlate with children's satisfaction with life and well-being (Waters, 2015). Especially for teenagers, character strengths are shown to be strongly associated with life satisfaction, love, gratitude, hope, and enjoyment (Niemiec, 2013). On the other hand, infants and children from 3 to 9 years perceiving themselves as happy have also shown the character strengths of love, hope, and zest, as reported by their parents (Park \& Peterson, 2009; Niemiec, 2013). Moreover, based on a study of identical and fraternal twins, the character strengths have been found to be moderately hereditary (Steger, Hicks, Kashdan, Krueger, \& Bouchard, 2007). Additionally, recent evidence showed that positive psychology interventions targeting character strengths (e.g. Proyer et al., 2015) and children of special populations (Shogren et al., 2015) were effective. Similar studies were carried out on psychologically distressed adults (see Sin \& Lyubomirsky, 2009).

Regarding the parenting process per se, the character strength of parental self-regulation was strongly related to child satisfaction but not to the parental satisfaction (Park \& Peterson, 2006; Niemiec, 2013). Finally, emphasizing and boosting character strengths by parents found to have a positive effect on the well-being of the children (Park, 2009; Waters, 2015) and generally creating a mutually beneficial situation (win-win) for the parent-child relationship, as already postulated in Authentic Happiness by Seligman (2002).

Summing up, Positive Psychology Parenting, as postulated by Seligman (2002) 
has been structured around the expression of unconditional, abundant positive emotions to the child, especially during infancy, and the development of the child's character strengths and values, through the mastery acquired by creativity and exploration developing by positive emotions.

\section{The Proposed Model for the Positive Psychology Parenting}

Seligman (2002) implicitly adopts the systemic view on parenting and family because he integrates family and child-raising in the center of a wider pattern of interactions proposing that the external environment (school, job, hobbies, marital and social relations) also influence and get influenced by positive emotions of all members. Only when every member of this open system has positive emotions, has acquired his/her strengths and has built education, carrier, and other activities around him/her can have a "good life". Positive family therapy also adopts the same view (Conoley \& Conoley, 2009; Conoley, Conoley, \& Pontrelli, 2014).

The definition of Positive Psychology Parenting based on this model (Seligman, 2002) is the following: Parenting is an integral part of good life, a life domain in which the parent can: a) Apply the principles of Positive Psychology to achieve personal life satisfaction and flourishing for himself/herself and his/her children; b) Increase the level of positive emotions of the child; c) Discover the character strengths of the child; d) Build every possible domain of child's life around his/her character strengths in order to strengthen them, as a means of balancing weaknesses and as a source of well-being.

The parenting of positive psychology was based on the pillars of Positive Psychology as follows: 1) Positive Emotions. Expressing positive emotions so as to have securely attached children ready and willing to explore their environment thus developing skills. 2) Character Strengths. Encouraging, naming and enhancing every character strength and value that appears along the way.

The actual model of positive psychology parenting was defined as follows by Seligman (2002) and it is essentially related to the process of building positive emotions first and then character strengths and virtues (see also Figure 2):

- Up to the age of six, the emphasis of positive psychology parenting is primarily put on the increase of the child's positive emotions, showing abundant and unconditional positive emotions.

- Then positive emotions through their broadening effect (Fredrickson, 1998, 2001) boost exploration, creativity, and resourcefulness.

- Exploration and creativity build skills, abilities and more positive emotions (upward spiral; Fredrickson, 1998, 2001).

- Throughout this process of acquiring mastery through play, character strengths and values gradually appear. On the appearance of each character strength or value, the parent should praise, name and encourage the child (positive reinforcement). This process is more effective if the parent acts as a role model (Bandura, 1997)

- By positive reinforcement, child identifies potential sources of positive emotions such as love, interest, or praise. Consequently, he/she will repeat the 


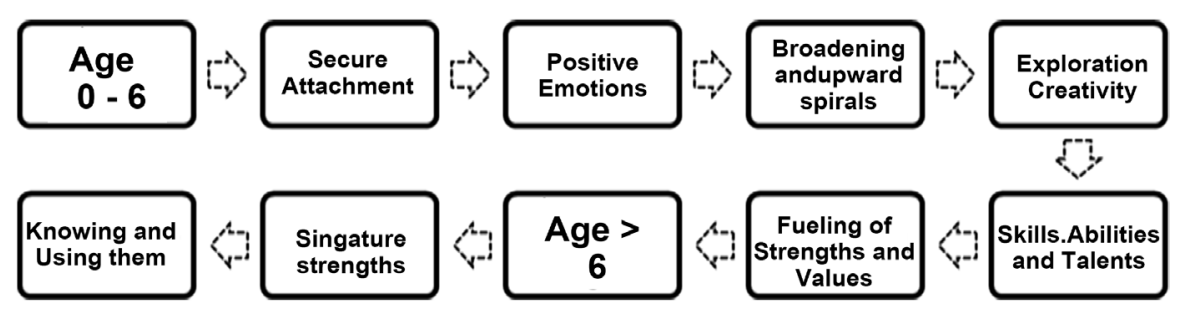

Figure 2. The proposed model of positive psychology parenting as defined by Seligman (2002).

strength in an attempt to receive again the same positive emotions from significant others. By the age of six, in most cases, character strengths start to appear more consistently.

- During this process, some character strength attempts are successful and others are not.

- Eventually, the child stops showing strengths that in the past triggered a failure and starts repeating others linked to more successful attempts.

- Finally, some strengths and values are more intense and frequent. These are probably the signature strengths of the child.

- If parents tailor his/her education, skills, activities and later career on the signature strengths and values, the child will have higher probabilities of achieving a "good life".

- Positive emotions expressed by parents at any point fuel the appearance of character strengths and boost parents' own flourishing.

However, for the above parenting model to be able to take place and potentially succeed certain basic parenting conditions must be met as described by Bradley and Caldwell (1995; Bradley, 2002). They proposed a set of parenting tasks required as a prerequisite for healthy child development: 1) sustenance (survival and biological integrity), 2) stimulation (cognitive and social-emotional stimulation), 3) support, 4) structure, and 5) surveillance. The first three tasks are based on what was defined as basic needs in Maslow's Hierarchy of needs (1975, and Ford \& Lerner, 1992 as commented by Bradley, 2002). The last two prerequisites are supporting the first three to contingently meet every child's needs (Bradley, 2002). Besides, for well-being to be accomplished basic needs must be met (Ryan \& Deci, 2000; Boniwell, 2012).

\section{Conclusion}

Empirical research has been the main tool of the Positive Psychology Movement (Seligman, 2009). In spite of the rich empirical literature (Boniwell, 2012), Positive Psychology parenting research is in its infancy. However, those Positive Psychology parenting principles have been postulated (Seligman, 2002), almost ever since Positive Psychology movement started (Seligman \& Csikszentmihalyi, 2000). Perhaps this gap could be attributed to a relatively blurred image due to the use of the term "positive" concurrently by positive discipline (Nelsen, 1979; 
Durrant, 2011), positive parenting (Sanders, 2003, Triple P-Positive Parenting Program) and Positive Psychology (Seligman \& Csikszentmihalyi, 2000). Despite this parallel use of the term "positive", in the case of the first two, the term "positive" basically refers to the non-punitive, or firm and kind parenting style. Additionally, they are mainly (but not exclusively) intended for special populations (Durrant, 2011; Pickering \& Sanders, 2016) seeking prevention and treatment. In the case of Positive Psychology, the term "positive" refers to the broadening and building effect of positive emotions (Fredrickson, 1998, 2001; Seligman, 2002), the target population is all normally adjusted children, and the purpose is not help the child reach zero (i.e. the prevention and treatment goal of "psychology as usual") but to move from plus 2 to as high as possible pursuing flourishing, in line with the purpose of positive psychology. To put it in a nutshell, positive discipline and positive parenting differ from positive psychology parenting in ways equivalent to the differences of "psychology as usual" from positive psychology.

\section{References}

Ackerman, B. P., Brown, E. D., \& Izard, C. E. (2004). The Relations between Contextual Risk, Earned Income, and the School Adjustment of Children from Economically Disadvantaged Families. Developmental Psychology, 40, 204-216.

https://doi.org/10.1037/0012-1649.40.2.204

Adamson, M., Morawska, A., \& Sanders, M. R. (2013). Childhood Feeding Difficulties: A Randomized Controlled Trial of a Group-Based Parenting Intervention. Journal of Developmental \& Behavioral Pediatrics, 34, 293-302.

https://doi.org/10.1097/DBP.0b013e3182961a38

Ainsworth, M. D. S., Blehar, M. C., \& Waters, E. (1978). Patterns of Attachment: A Psychological Study of the Strange Situation. Hillsdale, NJ: Earlbaum.

Allan, B. A., \& Duffy, R. D. (2014). Examining Moderators of Signature Strengths Use and Well-Being: Calling and Signature Strengths Level. Journal of Happiness Studies, 15, 323-337. https://doi.org/10.1007/s10902-013-9424-0

Bakeman, R., \& Brown, J. V. (1980). Early Interaction: Consequences for Social and Mental Development at Three Years. Child Development, 51, 437-447.

https://doi.org/10.2307/1129277

Bandura, A. (1997). Editorial. American Journal of Health Promotion, 12, 8-10. https://doi.org/10.4278/0890-1171-12.1.8

Baumrind, D. (1967). Child Care Practices Anteceding Three Patterns of Preschool Behavior. Genetic Psychology Monographs, 75, 43-88.

Baumrind, D. (1971). Current Patterns of Parental Authority. Developmental Psychology, 4, 1-103. https://doi.org/10.1037/h0030372

Baumrind, D. (1991). The Influence of Parenting Style on Adolescent Competence and Substance Use. The Journal of Early Adolescence, 11, 56-95.

https://doi.org/10.1177/0272431691111004

Bee, H. L., Barnard, K. E., Eyres, S. J., Gray, C. A., Hammond, M. A., Spietz, A. L. et al. (1982). Prediction of IQ and Language Skill from Perinatal Status, Child Performance, Family Characteristics, and Mother-Infant Interaction. Child Development, 53, 11341156. https://doi.org/10.2307/1129003

Belsky, J. (2015). Social-Contextual Determinants of Parenting. In R. E. Tremblay, M. 
Boivin, R. De V. Peters, \& R. E. Tremblay (Eds.),Encyclopedia on Early Childhood Development (pp. 60-64). Montreal: Centre of Excellence for Early Childhood Development and Strategic Knowledge Cluster on Early Child Development.

Belsky, J., Melhuish, E., Barnes, J., Leyland, A. H., \& Romaniuk, H. (2006). Effects of Sure Start Local Programmes on Children and Families: Early Findings from a Quasi-Experimental, Cross Sectional Study. BMJ, 332, 1476. https://doi.org/10.1136/bmj.38853.451748.2F

Bishop, S. J., \& Rothbaum, F. (1992). Parents' Acceptance of Control Needs and Preschoolers' Social Behaviour: A Longitudinal Study. Canadian Journal of Behavioural Science/Revue Canadienne des Sciences du Comportement, 24, 171-185. https://doi.org/10.1037/h0078705

Boniwell, I. (2012). Positive Psychology in a Nutshell: The Science of Happiness (3rd ed.). London: McGraw-Hill Education.

Bornstein, L., \& Bornstein, M. H. (2007). Parenting Styles and Child Social Development. In R. E. Tremblay, M. Boivin, R. De V. Peters, \& R. E. Tremblay (Eds.), Encyclopedia on Early Childhood Development. Montreal: Centre of Excellence for Early Childhood Development and Strategic Knowledge Cluster on Early Child Development.

Bornstein, M. H. (2002). Parenting Infants. In M. H. Borstein (Ed.), Handbook of Parenting: Children and Parenting (2nd ed., Vol. 1, pp. 3-43). Mahwah, NJ: Erlbaum.

Bornstein, M. H., \& Cheah, C. S. (2006). The Place of "Culture and Parenting" in the Ecological Contextual Perspective on Developmental Science. In K. H. Rubin \& O. B. Chung (Eds.), Parenting Beliefs, Behaviors, and Parent-Child Relations: A Cross-Cultural Perspective (pp. 3-33). New York, NY: Psychology Press.

Bowlby, J. (1969). Attachment and Loss: Attachment (Vol. 1, Pelican ed.). London: Penguin.

Bradley, R. H. (2002). Environment and Parenting. In Handbook of Parenting: Vol. 2: Biology and Ecology of Parenting (2nd ed., pp. 281-314). Mahwah, NJ: Lawrence Erlbaum Associates.

Bradley, R. H., \& Caldwell, B. M. (1995). Caregiving and the Regulation of Child Growth and Development: Describing Proximal Aspects of Caregiving Systems. Developmental Review, 15, 38-85. https://doi.org/10.1006/drev.1995.1002

Briesmeister, J. M., \& Schaefer, C. E. (Eds.) (2007). Handbook of Parent Training: Helping Parents Prevent and Solve Problem Behaviors. Hoboken, NJ: John Wiley \& Sons.

Bronfenbrenner, U. (1977). Toward an Experimental Ecology of Human Development. American Psychologist, 32, 513-531. https://doi.org/10.1037/0003-066X.32.7.513

Brown, K. W., \& Ryan, R. M. (2004). Perils and Promise in Defining and Measuring Mindfulness: Observations from Experience. Clinical Psychology: Science and Practice, 11, 242-248. https://doi.org/10.1093/clipsy.bph078

Burns, G. W. (2010). Happiness, Healing, Enhancement, Your Casebook Collection for Applying Positive Psychology in Therapy. Hoboken, NJ: Wiley.

Cameron, K. S., Dutton, J. E., Quinn, R. E., \& Wrzesniewski, A. (2003). Developing a Discipline of Positive Organizational Scholarship. In K. Cameron, J. Dutton, \& R. Quinn (Eds.), Positive Organizational Scholarship: Foundations of a New Discipline (pp. 361-370). San Francisco, CA: Berrett-Kohler

Caspi, A., Moffitt, T. E., Morgan, J., Rutter, M., Taylor, A., Arseneault, L. et al. (2004). Maternal Expressed Emotion Predicts Children's Antisocial Behavior Problems: Using Monozygotic-Twin Differences to Identify Environmental Effects on Behavioral Development. Developmental Psychology, 40, 149-161. 
https://doi.org/10.1037/0012-1649.40.2.149

Catalano, R., Berglund, M. L., Ryan, J. A., Lonczak, H. S., \& Hawkins, J. D. (1999). Positive Youth Development in the United States: Research Findings on Evaluations of Positive Youth Development Programs. Washington DC: Department of Health and Human Services.

Clarke-Stewart, K. A. (1973). Interactions between Mothers and Their Young Children: Characteristics and Consequences. Monographs of the Society for Research in Child Development, 38, 1-109. https://doi.org/10.2307/1165928

Conger, R. D., Conger, K. J., Elder, G. H., Lorenz, F. O., Simons, R. L., \& Whitbeck, L. B. (1993). Family Economic Stress and Adjustment of Early Adolescent Girls. Developmental Psychology, 29, 206-219. https://doi.org/10.1037/0012-1649.29.2.206

Conoley, C. W., \& Conoley, J. C. (2009). Positive Psychology and Family Therapy. Hoboken, NJ: Wiley.

Conoley, C. W., Conoley, J. C., \& Pontrelli, M. E. (2014). Positive Family Therapy Interventions. In A. C. Parks, \& S. M. Schueller (Eds.), The Wiley Blackwell Handbook of Positive Psychological Interventions (pp. 233-254). Hoboken, NJ: John Wiley \& Sons, Inc. https://doi.org/10.1002/9781118315927.ch13

Csikszentmihalyi, M. (1975/2000). Beyond Boredom and Anxiety: Experiencing Flow in Work and Play (2nd ed.). San Francisco, CA: Jossey Bass.

Danner, D. D., Snowdon, D. A., \& Friesen, W. V. (2001). Positive Emotions in Early Life and Longevity: Findings from the Nun Study. Journal of Personality and Social Psychology, 80, 804-813. https://doi.org/10.1037/0022-3514.80.5.804

Darwin, C. (1871). The Descent of Man. The Great Books of the Western World, 49, 320.

De Wolff, M. S., \& van Ijzendoorn, M. H. (1997). Sensitivity and Attachment: A Meta-Analysis on Parental Antecedents of Infant Attachment. Child Development, 68, 571-591. https://doi.org/10.1111/j.1467-8624.1997.tb04218.x

Diener, E. (1984). Subjective Well-Being. Psychological Bulletin, 95, 542-575. https://doi.org/10.1037/0033-2909.95.3.542

Diener, E. (2000). Subjective Well-Being: The Science of Happiness and a Proposal for a National Index. American Psychologist, 55, 34-43. https://doi.org/10.1037/0003-066X.55.1.34

Diener, E., \& Seligman, M. E. (2004). Beyond Money: Toward an Economy of Well-Being. Psychological Science in the Public Interest, 5, 1-31. https://doi.org/10.1111/j.0963-7214.2004.00501001.x

Diener, E., Colvin, C. R., Pavot, W. G., \& Allman, A. (1991). The Psychic Costs of Intense Positive Affect. Journal of Personality and Social Psychology, 61, 492-503. https://doi.org/10.1037/0022-3514.61.3.492

Diener, E., Nickerson, C., Lucas, R. E., \& Sandvik, E. (2002). Dispositional Affect and Job Outcomes. Social Indicators Research, 59, 229-259.

https://doi.org/10.1023/A:1019672513984

Diener, E., Wirtz, D., Biswas-Diener, R., Tov, W., Kim-Prieto, C., Choi, D. W., \& Oishi, S. (2009). New Measures of Well-Being. In E. Diener (Ed.), Assessing Well-Being (pp. 247-266). Dordrecht: Springer. https://doi.org/10.1007/978-90-481-2354-4_12

Diener, E., Wirtz, D., Tov, W., Kim-Prieto, C., Choi, D. W., Oishi, S., \& Biswas-Diener, R. (2010). New Well-Being Measures: Short Scales to Assess Flourishing and Positive and Negative Feelings. Social Indicators Research, 97, 143-156. https://doi.org/10.1007/s11205-009-9493-y

Doyle, W. J., Gentile, D. A., \& Cohen, S. (2006). Emotional Style, Nasal Cytokines, and 
Illness Expression after Experimental Rhinovirus Exposure. Brain, Behavior, and Immunity, 20, 175-181. https://doi.org/10.1016/j.bbi.2005.05.005

Dreikurs, R., \& Soltz, V. (1964). Children: The Challenge. New York, NY: Hawthorn Books.

Dunn, J. R., \& Schweitzer, M. E. (2005). Feeling and Believing: The Influence of Emotion on Trust. Journal of Personality and Social Psychology, 88, 736-748. https://doi.org/10.1037/0022-3514.88.5.736

Durlak, J. A. (2003). The Long-Term Impact of Preschool Prevention Programs: A Commentary. Prevention \& Treatment, 6, Article ID: 32c.

Durrant, J. (2011). Positive Discipline: What It Is and How to Do It (2nd ed.). Sweden: Save the Children Sweden.

Dwairy, M., \& Dor, A. (2009). Parenting and Psychological Adjustment of Adolescent Immigrants in Israel. Journal of Family Psychology, 23, 416-425. https://doi.org/10.1037/a0015830

Eades, J. M. F. (2008). Celebrating Strengths: Building Strengths-Based Schools. Coventry: CAPP Press.

Feldman, R. (2007). Parent-Infant Synchrony and the Construction of Shared Timing; Physiological Precursors, Developmental Outcomes, and Risk Conditions. Journal of Child Psychology and Psychiatry, 48, 329-354.

https://doi.org/10.1111/j.1469-7610.2006.01701.x

Feldman, S. S., Rosenthal, D. A., Mont-Reynaud, R., Lau, S., \& Leung, K. (1991). Ain't Misbehavin': Adolescent Values and Family Environments as Correlates of Misconduct in Cross-National Study of Chinese, Australian, and American Youth. Journal of Research in Adolescence, 1, 109-134. https://doi.org/10.1207/s15327795jra0102_1

Ford, D. H., \& Lerner, R. M. (1992). Developmental Systems Theory: An Integrative Approach. Thousand Oaks, CA: Sage Publications, Inc.

Fredrickson, B. (2009). Positivity: Groundbreaking Research Reveals How to Embrace the Hidden Strength of Positive Emotions, Overcome Negativity, and Thrive. New York, NY: Crown.

Fredrickson, B. L. (1998). Cultivated Emotions: Parental Socialization of Positive Emotions and Self-Conscious Emotions. Psychological Inquiry, 9, 279-281. https://doi.org/10.1207/s15327965pli0904_4

Fredrickson, B. L. (2001). The Role of Positive Emotions in Positive Psychology: The Broaden-and-Build Theory of Positive Emotions. American Psychologist, 56, 218-226. https://doi.org/10.1037/0003-066X.56.3.218

Fredrickson, B. L. (2003). The Value of Positive Emotions: The Emerging Science of Positive Psychology Is Coming to Understand Why It's Good to Feel Good. American Scientist, 91, 330-335.

Fredrickson, B. L. (2013a). Positive Emotions Broaden and Build. In Advances in Experimental Social Psychology (Vol. 47, pp. 1-53). Cambridge, MA: Academic Press. https://doi.org/10.1016/B978-0-12-407236-7.00001-2

Fredrickson, B. L. (2013b). Updated Thinking on Positivity Ratios. American Psychologist, 68, 814-822. https://doi.org/10.1037/a0033584

Fredrickson, B. L., \& Branigan, C. (2005). Positive Emotions Broaden the Scope of Attention and Thought-Action Repertoires. Cognition \& Emotion, 19, 313-332. https://doi.org/10.1080/02699930441000238

Fredrickson, B. L., \& Levenson, R. W. (1998). Positive Emotions Speed Recovery from the Cardiovascular Sequelae of Negative Emotions. Cognition \& Emotion, 12, 191-220. 
https://doi.org/10.1080/026999398379718

Fredrickson, B. L., \& Losada, M. F. (2005). Positive Affect and the Complex Dynamics of Human Flourishing. American Psychologist, 60, 678-686.

https://doi.org/10.1037/0003-066X.60.7.678

Fredrickson, B. L., Cohn, M. A., Coffey, K. A., Pek, J., \& Finkel, S. M. (2008). Open Hearts Build Lives: Positive Emotions, Induced through Loving-Kindness Meditation, Build Consequential Personal Resources. Journal of Personality and Social Psychology, 95, 1045-1062. https://doi.org/10.1037/a0013262

Fredrickson, B. L., Mancuso, R. A., Branigan, C., \& Tugade, M. M. (2000). The Undoing Effect of Positive Emotions. Motivation and Emotion, 24, 237-258.

https://doi.org/10.1023/A:1010796329158

Freud, S. (1962). The Ego and the ID: The Standard Edition. New York, NY: Norton.

Gable, S. L., \& Haidt, J. (2005). What (and Why) Is Positive Psychology? Review of General Psychology, 9, 103-110. https://doi.org/10.1037/1089-2680.9.2.103

Gardner, H., Csikszentmihalyi, M., \& Damon, W. (2001). Good Work: When Excellence and Ethics Meet. New York, NY: Basic Books.

Gardner, R. A. (1987). The Parental Alienation Syndrome and the Differentiation between Fabricated and Genuine Child Sex Abuse. Cresskill, NJ: Creative Therapeutics.

Garland, E. L., Fredrickson, B., Kring, A. M., Johnson, D. P., Meyer, P. S., \& Penn, D. L. (2010). Upward Spirals of Positive Emotions Counter Downward Spirals of Negativity: Insights from the Broaden-and-Build Theory and Affective Neuroscience on the Treatment of Emotion Dysfunctions and Deficits in Psychopathology. Clinical Psychology Review, 30, 849-864. https://doi.org/10.1016/j.cpr.2010.03.002

George, J. M., \& Zhou, J. (2007). Dual Tuning in a Supportive Context: Joint Contributions of Positive Mood, Negative Mood, and Supervisory Behaviors to Employee Creativity. Academy of Management Journal, 50, 605-622.

https://doi.org/10.5465/amj.2007.25525934

Goldsmith, H. H., \& Alansky, J. A. (1987). Maternal and Infant Temperamental Predictors of Attachment: A Meta-Analytic Review. Journal of Consulting and Clinical Psychology, 55, 805-816. https://doi.org/10.1037/0022-006X.55.6.805

Govindji, R., \& Linley, P. A. (2007). Strengths Use, Self-Concordance and Well-Being: Implications for Strengths Coaching and Coaching Psychologists. International Coaching Psychology Review, 2, 143-153.

Gray, J. (2007). Children Are from Heaven. London: Routledge.

Griffin, K. W., Botvin, G. J., Scheier, L. M., Diaz, T., \& Miller, N. L. (2000). Parenting Practices as Predictors of Substance Use, Delinquency, and Aggression among Urban Minority Youth: Moderating Effects of Family Structure and Gender. Psychology of Addictive Behaviors, 14, 174-184. https://doi.org/10.1037/0893-164X.14.2.174

Harker, L., \& Keltner, D. (2001). Expressions of Positive Emotion in Women's College Yearbook Pictures and Their Relationship to Personality and Life Outcomes across Adulthood. Journal of Personality and Social Psychology, 80, 112-124. https://doi.org/10.1037/0022-3514.80.1.112

Harkness, S., \& Super, C. M. (2002). Culture and Parenting. In Handbook of Parenting: Vol. 2: Biology and Ecology of Parenting (2nd ed., pp. 253-280). Mahwah, NJ: Lawrence Erlbaum Associates.

Hefferon, K., \& Boniwell, I. (2011). Positive Psychology: Theory, Research and Applications. UK: McGraw-Hill Education.

Hejmadi, A., Waugh, C. E., Otake, K., \& Fredrickson, B. L. (2008). Cross-Cultural Evi- 
dence That Positive Emotions Broaden Views of Self to Include Close Others. Manuscript in preparation.

Hodapp, R. M., \& Ly, T. M. (2005). Parenting Children with Developmental Disabilities. In T. Luster, \& L. Okagaki (Eds.), Parenting: An Ecological Perspective (pp. 177-201). Mahwah, NJ: Erlbaum.

Holden, G. W. (1983). Avoiding Conflict: Mothers as Tacticians in the Supermarket. Child Development, 54, 233-240. https://doi.org/10.2307/1129881

Holden, G. W. (1985). How Parents Create a Social Environment via Proactive Behavior. In T. Garling, \& J. Valsiner (Eds.), Children within Environments (pp. 193-215). New York, NY: Plenum.

Huppert, F. A., \& So, T. T. (2013). Flourishing across Europe: Application of a New Conceptual Framework for Defining Well-Being. Social Indicators Research, 110, 837-861. https://doi.org/10.1007/s11205-011-9966-7

Hurley, D., Chiodo, D., Leschied, A., \& Whitehead, P. (2003). Correlates of a Measure of Parenting Capacity with Parent and Child Characteristics in a Child Welfare Sample. London, ON: King's College, The University of Western Ontario.

Huta, V. (2012). Linking Peoples' Pursuit of Eudaimonia and Hedonia with Characteristics of Their Parents: Parenting Styles, Verbally Endorsed Values, and Role Modeling. Journal of Happiness Studies, 13, 47-61. https://doi.org/10.1007/s10902-011-9249-7

Jach, H. K., Sun, J., Loton, D., Chin, T. C., \& Waters, L. E. (2018). Strengths and Subjective Wellbeing in Adolescence: Strength-Based Parenting and the Moderating Effect of Mindset. Journal of Happiness Studies, 19, 567-586.

Jahoda, M. (1958). Joint Commission on Mental Health and Illness Monograph Series: Vol. 1. Current Concepts of Positive Mental Health. New York, NY: Basic Books. https://doi.org/10.1037/11258-000

Kahneman, D., Diener, E., \& Schwarz, N. (Eds.) (1999). Well-Being: Foundations of Hedonic Psychology. New York, NY: Russell Sage Foundation.

Keyes, C. L. (2002). The Mental Health Continuum: From Languishing to Flourishing in Life. Journal of Health and Social Behavior, 43, 207-222. https://doi.org/10.2307/3090197

Kochanska, G., Forman, D. R., Aksan, N., \& Dunbar, S. B. (2005). Pathways to Conscience: Early Mother-Child Mutually Responsive Orientation and Children's Moral Emotion, Conduct, and Cognition. Journal of Child Psychology and Psychiatry, 46, 19-34. https://doi.org/10.1111/j.1469-7610.2004.00348.x

Kuczynski, L. (2003). Beyond Bidirectionality: Bilateral Conceptual Frameworks for Understanding Dynamics in Parent-Child Relations. In L. Kuczynski (Ed.), Handbook of Dynamics in Parent-Child Relations (pp. 3-24). Thousand Oaks, CA: SAGE Publishing. https://doi.org/10.4135/9781452229645.n1

Larson, R. W. (2000). Toward a Psychology of Positive Youth Development. American Psychologist, 55, 170-183. https://doi.org/10.1037/0003-066X.55.1.170

Lerner, R. M., Rothbaum, F., Boulos, S., \& Castellino, D. R. (2002). Developmental Systems Perspective on Parenting. In M. H. Bornstein (Ed.), Handbook of Parenting: Biology and Ecology of Parenting (pp. 315-344). Mahwah, NJ: Lawrence Erlbaum Associates Publishers.

Linley, P. A., \& Joseph, S. (2015). Positive Psychology in Practice (2nd ed.). Hoboken, NJ: Wiley.

Linley, P. A., Joseph, S., Maltby, J., Harrington, S., \& Wood, A. M. (2009). Positive Psychology Applications. In C. R. Snyder, \& Shane J. Lopez (Eds.), The Oxford Handbook 
of Positive Psychology. Oxford: Oxford University Press. https://doi.org/10.1093/oxfordhb/9780195187243.013.0005

Lott, L., \& Nelsen, J. (2000). Positive Discipline for Teenagers, Revised 2nd Edition: Empowering Your Teens and Yourself through Kind and Firm Parenting. New York, NJ: Three Rivers Press.

Lyons-Ruth, K., Zoll, D., Connell, D., \& Grunebaum, H. U. (1989). Family Deviance and Family Disruption in Childhood: Associations with Maternal Behavior and Infant Maltreatment during the First Two Years of Life. Development and Psychopathology, 1, 219-236. https://doi.org/10.1017/S0954579400000420

Maccoby, E. E. (1992). The Role of Parents in the Socialization of Children: An Historical Overview. Developmental Psychology, 28, 1006-1017.

https://doi.org/10.1037/0012-1649.28.6.1006

Maccoby, E. E., \& Martin, J. A. (1983). Socialization in the Context of the Family: Parent-Child Interaction. In E. M. Hetherington, \& P. H. Mussen (Eds.), Handbook of Child Psychology: Vol. 4. Socialization, Personality, and Social Development (pp. 1-101). New York, NY: Wiley.

Maslow, A. (1968). Some Educational Implications of the Humanistic Psychologies. Harvard Educational Review, 38, 685-696.

https://doi.org/10.17763/haer.38.4.j07288786v86w660

Maslow, A. H. (1975). Motivation and Personality. London: Harper \& Row.

McGovern, T. V., \& Miller, S. L. (2008). Integrating Teacher Behaviors with Character Strengths and Virtues for Faculty Development. Teaching of Psychology, 35, 278-285. https://doi.org/10.1080/00986280802374609

Milevsky, A., Schlechter, M., Netter, S., \& Keehn, D. (2007). Maternal and Paternal Parenting Styles in Adolescents: Associations with Self-Esteem, Depression and Life-Satisfaction. Journal of Child and Family Studies, 16, 39-47. https://doi.org/10.1007/s10826-006-9066-5

Moore, K. A., \& Keyes, C. L. (2003). A Brief History of Well-Being in Children and Adults. In M. H. Bornstein, L. Davidson, C. L. M. Keyes, \& K. A. Moore (Eds.), Crosscurrents in Contemporary Psychology. Well-Being: Positive Development across the Life Course (pp. 1-11). Mahwah, NJ: Lawrence Erlbaum Associates Publishers.

Moore, K. A., \& Lippman, L. H. (Eds.) (2005). What Do Children Need to Flourish? Conceptualizing and Measuring Indicators of Positive Development (Vol. 3). Berlin/Heidelberg, Germany: Springer Science \& Business Media. https://doi.org/10.1007/b100487

Mussen, P. H., Conger, J. J., Kagan, J., \& Huston, A. C. (1990). Intelligence and Achievement. In P. Mussen, J. Conger, J. Kagan, \& A. Huston (Eds.), Child Development and Personality (pp. 325-378). Nueva York: Harper Row Publishers.

Mussen, P., Harris, S., Rutherford, E., \& Keasey, C. B. (1970). Honesty and Altruism among Preadolescents. Developmental Psychology, 3, 169-194. https://doi.org/10.1037/h0029586

Nelsen, J. (1979). The Effectiveness of Adlerian Parent and Teacher Study Groups in Changing Child Maladaptive Behavior in a Positive Direction. Dissertation, San Francisco, CA: The University of San Francisco.

Nelsen, J. (2006). Positive Discipline. New York, NY: Random House.

Nelsen, J., Lott, L., \& Glenn, H. S. (2000). Positive Discipline in the Classroom: Developing Mutual Respect, Cooperation, and Responsibility in Your Classroom. New York, NY: Three Rivers Press. 
Ng, V., Cao, M., Marsh, H. W., Tay, L., \& Seligman, M. E. (2017). The Factor Structure of the Values in Action Inventory of Strengths (VIA-IS): An Item-Level Exploratory Structural Equation Modeling (ESEM) Bifactor Analysis. Psychological Assessment, 29, 1053-1058. https://doi.org/10.1037/pas0000396

Niemiec, R. M. (2013). Mindfulness and Character Strengths. Boston, MA: Hogrefe Publishing.

Oishi, S., Diener, E., \& Lucas, R. E. (2007). The Optimum Level of Well-Being: Can People Be Too Happy? Perspectives on Psychological Science, 2, 346-360. https://doi.org/10.1111/j.1745-6916.2007.00048.x

Ostir, G. V., Markides, K. S., Black, S. A., \& Goodwin, J. S. (2000). Emotional Well-Being Predicts Subsequent Functional Independence and Survival. Journal of the American Geriatrics Society, 48, 473-478. https://doi.org/10.1111/j.1532-5415.2000.tb04991.x

Papoušek, H., \& Papoušek, M. (2002). Intuitive Parenting. In M. H, Bornstein (Ed.), Handbook of Parenting: Vol. 2. Biology and Ecology of Parenting (2nd ed., 183-203). Mahwah, NJ; Erlbaum

Park, N. (2004). The Role of Subjective Well-Being in Positive Youth Development. The Annals of the American Academy of Political and Social Science, 591, 25-39. https://doi.org/10.1177/0002716203260078

Park, N. (2009). Strengths of Character. In S. Lopez (Ed.), The Encyclopedia of Positive Psychology (pp. 137-140). Chichester: Blackwell Publishing Ltd.

Park, N., \& Peterson, C. (2006). Moral Competence and Character Strengths among Adolescents: The Development and Validation of the Values in Action Inventory of Strengths for Youth. Journal of Adolescence, 29, 891-909. https://doi.org/10.1016/j.adolescence.2006.04.011

Park, N., \& Peterson, C. (2009). Character Strengths: Research and Practice. Journal of College and Character, 10. https://doi.org/10.2202/1940-1639.1042

Patterson, C. J. (1992). Children of Lesbian and Gay Parents. Child Development, 63, 1025-1042. https://doi.org/10.2307/1131517

Peterson, C. (2006). A Primer in Positive Psychology. Oxford: Oxford University Press.

Peterson, C. (2013). Looking Forward through the Lifespan: Developmental Psychology. Sydney, NSW: Pearson Higher Education AU.

Peterson, C., \& Park, N. (2009). Classifying and Measuring Strengths of Character. In S. J. Lopez, \& C. R. Snyder (Eds.), Oxford Library of Psychology. Oxford Handbook of Positive Psychology (pp. 25-33). New York, NY: Oxford University Press. https://doi.org/10.1093/oxfordhb/9780195187243.013.0004

Peterson, C., \& Seligman, M. E. (2004). Character Strengths and Virtues: A Handbook and Classification (Vol. 1). New York, NY: Oxford University Press.

Peterson, C., Park, N., \& Seligman, M. E. (2005). Orientations to Happiness and Life Satisfaction: The Full Life versus the Empty Life. Journal of Happiness Studies, 6, 25-41. https://doi.org/10.1007/s10902-004-1278-Z

Pettit, G. S., \& Bates, J. E. (1989). Family Interaction Patterns and Children's Behavior Problems from Infancy to 4 Years. Developmental Psychology, 25, 413-420. https://doi.org/10.1037/0012-1649.25.3.413

Pettit, G. S., Bates, J. E., \& Dodge, K. A. (1993). Family Interaction Patterns and Children's Conduct Problems at Home and School: A Longitudinal Perspective. School Psychology Review, 22, 403-420.

Pickering, J. A., \& Sanders, M. R. (2016). Reducing Child Maltreatment by Making Parenting Programs Available to All Parents: A Case Example Using the Triple P-Positive 
Parenting Program. Trauma, Violence, \& Abuse, 17, 398-407. https://doi.org/10.1177/1524838016658876

Pluess, M., \& Belsky, J. (2010). Differential Susceptibility to Parenting and Quality Child Care. Developmental Psychology, 46, 379-390. https://doi.org/10.1037/a0015203

Pollard, E., \& Rosenberg, M. (2003). The Strength-Based Approach to Child Well-Being: Let's Begin with the End in Mind. In M. Bornstein, \& L. Davidson (Eds.), Well-Being: Positive Development across the Life Course (pp. 13-32). Mahwah, NJ: Lawrence Erlbaum Associates Publishers.

Proctor, C., Linley, P. A., \& Maltby, J. (2010). Very Happy Youths: Benefits of Very High Life Satisfaction among Adolescents. Social Indicators Research, 98, 519-532. https://doi.org/10.1007/s11205-009-9562-2

Proyer, R. T., Gander, F., Wellenzohn, S., \& Ruch, W. (2015). Strengths-Based Positive Psychology Interventions: A Randomized Placebo-Controlled Online Trial on LongTerm Effects for a Signature Strengths vs. a Lesser Strengths-Intervention. Frontiers in Psychology, 6, 456. https://doi.org/10.3389/fpsyg.2015.00456

Quinlan, D., Swain, N., \& Vella-Brodrick, D. A. (2012). Character Strengths Interventions: Building on What We Know for Improved Outcomes. Journal of Happiness Studies, 13, 1145-1163. https://doi.org/10.1007/s10902-011-9311-5

Raghunathan, R., \& Trope, Y. (2002). Walking the Tightrope between Feeling Good and Being Accurate: Mood as a Resource in Processing Persuasive Messages. Journal of Personality and Social Psychology, 83, 510-525. https://doi.org/10.1037/0022-3514.83.3.510

Rapee, R. M., Kennedy, S. J., Ingram, M., Edwards, S. L., \& Sweeney, L. (2010). Altering the Trajectory of Anxiety in At-Risk Young Children. American Journal of Psychiatry, 167, 1518-1525. https://doi.org/10.1176/appi.ajp.2010.09111619

Rasmussen, K. N. (2009). Effective Parenting. In S. Lopez (Ed.), The Encyclopedia of Positive Psychology (pp. 291-296). Chichester: Blackwell Publishing Ltd.

Repetti, R. L., Taylor, S. E., \& Seeman, T. E. (2002). Risky Families: Family Social Environments and the Mental and Physical Health of Offspring. Psychological Bulletin, 128, 330-366. https://doi.org/10.1037/0033-2909.128.2.330

Rilling, J. K., \& Mascaro, J. (2016). The Neural Correlates of Individual Variation in Paternal Nurturance. In J. D. Greene, I. Morrison, \& M. E. P. Seligman (Eds.), Positive Neuroscience. New York, NY: Oxford University Press. https://doi.org/10.1093/acprof:oso/9780199977925.003.0003

Rohner, R. P., Khaleque, A., \& Cournoyer, D. E. (2012). Introduction to Parental Acceptance-Rejection Theory.

Rowe, G., Hirsh, J. B., \& Anderson, A. K. (2007). Positive Affect Increases the Breadth of Attentional Selection. Proceedings of the National Academy of Sciences of the United States of America, 104, 383-388. https://doi.org/10.1073/pnas.0605198104

Russell, A., \& Russell, G. (1996). Positive Parenting and Boys' and Girls' Misbehaviour during a Home Observation. International Journal of Behavioral Development, 19, 291-307. https://doi.org/10.1177/016502549601900204

Ryan, R. M., \& Deci, E. L. (2000). Self-Determination Theory and the Facilitation of Intrinsic Motivation, Social Development, and Well-Being. American Psychologist, 55, 68-78. https://doi.org/10.1037/0003-066X.55.1.68

Ryan, R. M., \& Deci, E. L. (2001). On Happiness and Human Potentials: A Review of Research on Hedonic and Eudaimonic Well-Being. Annual Review of Psychology, 52, 141-166. https://doi.org/10.1146/annurev.psych.52.1.141 
Ryff, C. D., \& Keyes, C. L. M. (1995). The Structure of Psychological Well-Being Revisited. Journal of Personality and Social Psychology, 69, 719-727. https://doi.org/10.1037/0022-3514.69.4.719

Saegert, S., \& Winkel, G. H. (1990). Environmental Psychology. Annual Review of Psychology, 41, 441-477. https://doi.org/10.1146/annurev.ps.41.020190.002301

Sanders, M. R. (1999). Triple P-Positive Parenting Program: Towards an Empirically Validated Multilevel Parenting and Family Support Strategy for the Prevention of Behavior and Emotional Problems in Children. Clinical Child and Family Psychology Review, 2, 71-90. https://doi.org/10.1023/A:1021843613840

Sanders, M. R. (2008). Triple P-Positive Parenting Program as a Public Health Approach to Strengthening Parenting. Journal of Family Psychology, 22, 506-517. https://doi.org/10.1037/0893-3200.22.3.506

Sanders, M. R. (2012). Development, Evaluation, and Multinational Dissemination of the Triple P-Positive Parenting Program. Annual Review of Clinical Psychology, 8, 345-379. https://doi.org/10.1146/annurev-clinpsy-032511-143104

Sanders, M. R., Cleghorn, G., Shepherd, R. W., \& Patrick, M. (1996). Predictors of Clinical Improvement in Children with Recurrent Abdominal Pain. Behavioural and Cognitive Psychotherapy, 24, 27-38. https://doi.org/10.1017/S1352465800016817

Scales, P. C., Benson, P. L., Leffert, N., \& Blyth, D. A. (2000). Contribution of Developmental Assets to the Prediction of Thriving among Adolescents. Applied Developmental Science, 4, 27-46. https://doi.org/10.1207/S1532480XADS0401_3

Schueller, S. M., \& Parks, A. C. (2014). The Science of Self-Help. European Psychologist, 19, 145-155. https://doi.org/10.1027/1016-9040/a000181

Schwartz, S. H., Cieciuch, J., Vecchione, M., Davidov, E., Fischer, R., Beierlein, C. et al. (2012). Refining the Theory of Basic Individual Values. Journal of Personality and Social Psychology, 103, 663-688. https://doi.org/10.1037/a0029393

Seaton, C. L. (2009). Psychological Adjustment. In S. Lopez (Ed.), The Encyclopedia of Positive Psychology (pp. 291-296). Chichester: Blackwell Publishing Ltd.

Seligman, M. E. (1998). What Is the Good Life? APA Monitor, 29, 2.

Seligman, M. E. (2002). Authentic Happiness: Using the New Positive Psychology to Realize Your Potential for Lasting Fulfillment. New York, NY: Free Press.

Seligman, M. E. (2007). Learned Optimism: How to Change Your Mind and Your Life (3nd ed.). New York, NY: Vintage Books.

Seligman, M. E. (2009). Foreword. In S. Lopez (Ed.), The Encyclopedia of Positive Psychology (p. xix). Chichester: Blackwell Publishing Ltd.

Seligman, M. E. (2011). Flourish: A New Understanding of Happiness and Wellbeing and How to Achieve Them. London: Nicholas Brealey.

Seligman, M. E., \& Csikszentmihalyi, M. (2000). Positive Psychology: An Introduction. American Psychologist, 55, 5-14. https://doi.org/10.1037/0003-066X.55.1.5

Seligman, M. E., \& Pawelski, J. O. (2003). Positive Psychology: FAQS. Psychological Inquiry, 14, 159-163.

Seligman, M. E., Railton, P., Baumeister, R. F., \& Sripada, C. (2016). Homo Prospectus. Oxford: Oxford University Press.

Seligman, M. E., Steen, T. A., Park, N., \& Peterson, C. (2005). Positive Psychology Progress: Empirical Validation of Interventions. American Psychologist, 60, 410-421. https://doi.org/10.1037/0003-066X.60.5.410

Shogren, K. A., Wehmeyer, M. L., Palmer, S. B., Rifenbark, G. G., \& Little, T. D. (2015). 
Relationships between Self-Determination and Postschool Outcomes for Youth with Disabilities. The Journal of Special Education, 48, 256-267.

https://doi.org/10.1177/0022466913489733

Shoshani, A., \& Slone, M. (2013). Middle School Transition from the Strengths Perspective: Young Adolescents' Character Strengths, Subjective Well-Being, and School Adjustment. Journal of Happiness Studies, 14, 1163-1181.

https://doi.org/10.1007/s10902-012-9374-y

Sin, N. L., \& Lyubomirsky, S. (2009). Enhancing Well-Being and Alleviating Depressive Symptoms with Positive Psychology Interventions: A Practice-Friendly Meta-Analysis. Journal of Clinical Psychology, 65, 467-487. https://doi.org/10.1002/jclp.20593

Smith, K. E., Landry, S. H., \& Swank, P. R. (2000). The Influence of Early Patterns of Positive Parenting on Children's Preschool Outcomes. Early Education and Development, 11, 147-169. https://doi.org/10.1207/s15566935eed1102_2

Snyder, C. R. (2000). Genesis: The Birth and Growth of Hope. In C. R. Snyder (Ed.), Handbook of Hope (pp. 25-37). New York, NY: Academic Press. https://doi.org/10.1016/B978-012654050-5/50004-X

Snyder, C. R., \& Lopez, S. J. (2007). Positive Psychology: The Scientific and Practical EXplorations of Human Strengths. Thousand Oaks, CA: Sage Publications, Inc.

Snyder, C. R., Lopez, S. J., Aspinwall, L., Fredrickson, B. L., Haidt, J., Keltner, D. et al. (2002). The Future of Positive Psychology: A Declaration of Independence. In C. R. Snyder, \& S. J. Lopez (Eds.), Handbook of Positive Psychology (pp. 751-767). New York, NY: Oxford University Press.

Steger, M. F., Hicks, B. M., Kashdan, T. B., Krueger, R. F., \& Bouchard Jr., T. J. (2007). Genetic and Environmental Influences on the Positive Traits of the Values in Action Classification, and Biometric Covariance with Normal Personality. Journal of Research in Personality, 41, 524-539. https://doi.org/10.1016/j.jrp.2006.06.002

Suldo, S. M., Frank, M. J., Chappel, A. M., Albers, M. M., \& Bateman, L. P. (2014). American High School Students' Perceptions of Determinants of Life Satisfaction. Social Indicators Research, 118, 485-514. https://doi.org/10.1007/s11205-013-0436-2

Super, C. M., \& Harkness, S. (1986). The Developmental Niche: A Conceptualization at the Interface of Child and Culture. International Journal of Behavioral Development, 9, 545-569. https://doi.org/10.1177/016502548600900409

Super, C. M., \& Harkness, S. (1997). Modernization, Family Life, and Child Development in Kokwet. In T. S. Weisner, C. Bradley, \& P. L. Kilbride (Eds.), African Families and the Crisis of Social Change (pp. 341-353). New York, NY: Bergin and Garvey.

Tellegen, C. L., \& Sanders, M. R. (2014). A Randomized Controlled Trial Evaluating a Brief Parenting Program with Children with Autism Spectrum Disorders. Journal of Consulting and Clinical Psychology, 82, 1193-1200. https://doi.org/10.1037/a0037246

Teti, D. M., \& Candelaria, M. (2002). Parenting Competence. In M. H. Bornstein (Ed.), Handbook of Parenting: Vol. 4. Applied Parenting (2nd ed., pp. 149-180). Mahwah, NJ: Lawrence Erlbaum.

Tobach, E., \& Schneirla, T. C. (1968). The Biopsychology of Social Behavior of Animals. In R. E. Cooke, \& S. Levin (Eds.), Biologic Basis of Pediatric Practice (pp. 68-82). New York, NY: McGraw-Hill.

Trommsdorff, G. (2006). Parent-Child Relations over the Life-Span. A Cross-Cultural Perspective. In K. H. Rubin, \& O. B. Chung (Eds.), Parenting Beliefs, Behaviors, and Parent-Child Relations. A Cross-Cultural Perspective (pp. 143-183). New York, NY: Psychology Press.

United Nations Foundation, UNF (2006). United Nations Children's Rights Declara- 
tion-Report.

van Ijzendoorn, M. H., Bakermans-Kranenburg, M. J., \& Sagi-Schwartz, A. (2006). Attachment across Diverse Sociocultural Contexts: The Limits of Universality. In K. H. Rubin, \& O. B. Chung (Eds.), Parenting Beliefs, Behaviors, and Parent-Child Relations. A Cross-Cultural Perspective (pp. 107-142). New York, NY: Psychology Press.

Vittersø, J., Søholt, Y., Hetland, A., Thoresen, I. A., \& Røysamb, E. (2010). Was Hercules Happy? Some Answers from a Functional Model of Human Well-Being. Social Indicators Research, 95, 1. https://doi.org/10.1007/s11205-009-9447-4

von Bertalanffy, L. (1976). General System Theory: Foundations, Development, Applications (rev. ed.). New York, NY: George Braziller.

Wadlinger, H. A., \& Isaacowitz, D. M. (2006). Positive Mood Broadens Visual Attention to Positive Stimuli. Motivation and Emotion, 30, 87-99. https://doi.org/10.1007/s11031-006-9021-1

Waters, L. (2015). Strength-Based Parenting and Life Satisfaction in Teenagers. Advances in Social Sciences Research Journal, 2, 158-173. https://doi.org/10.14738/assrj.211.1551

Waugh, C. E., \& Fredrickson, B. L. (2006). Nice to Know You: Positive Emotions, Self-Other Overlap, and Complex Understanding in the Formation of a New Relationship. The Journal of Positive Psychology, 1, 93-106. https://doi.org/10.1080/17439760500510569

Weissberg, R. P., Kumpfer, K. L., \& Seligman, M. E. (2003). Prevention That Works for Children and Youth: An Introduction. American Psychologist, 58, 425-432.

https://doi.org/10.1037/0003-066X.58.6-7.425

Werner, E. E., \& Smith, R. (1982). Vulnerable but Invincible: A Study of Resilient Children. New York, NY: McGraw-Hill.

West, F., Sanders, M. R., Cleghorn, G. J., \& Davies, P. S. (2010). Randomised Clinical Trial of a family-Based Lifestyle Intervention for Childhood Obesity Involving Parents as the Exclusive Agents of Change. Behaviour Research and Therapy, 48, 1170-1179. https://doi.org/10.1016/j.brat.2010.08.008

Whiteman, S. D., McHale, S. M., \& Soli, A. (2011). Theoretical Perspectives on Sibling Relationships. Journal of Family Theory and Review, 3, 124-139. https://doi.org/10.1111/j.1756-2589.2011.00087.x

Whittingham, K., Sanders, M., McKinlay, L., \& Boyd, R. N. (2014). Interventions to Reduce Behavioral Problems in Children with Cerebral Palsy: An RCT. Pediatrics, 133, e1249-e1257. https://doi.org/10.1542/peds.2013-3620

Wood, A. M., \& Johnson, J. (2016). The Wiley Handbook of Positive Clinical Psychology. West Sussex: Wiley Blackwell. https://doi.org/10.1002/9781118468197

World Health Organization (WHO) (1978). A WHO Report on Social and Biological Effects on Perinatal Mortality, 1. Budapest: Statistical Publishing House. 